\title{
EFEKTIVITAS PEMBELAJARAN KONTEKSTUAL MODEL PENGAJARAN BERBASIS MASALAH DALAM MENINGKATKAN PRESTASI DAN PENGUASAAN MATERI PELAJARAN IPA SISWA KELAS II SD NEGERI 200403 PADANGSIDIMPUAN TAHUN PELAJARAN 2015/2016
}

\author{
SORLAN SIREGAR, S.Pd.
}

NIP: 196108311982012002.

Email: sorlansiregar@gmail.com

\section{abstrak}

Untuk bisa mempelajari sesuatu dengan baik, kita perlu mendengar,melihat, mengajukan pertanyaan tentangnya, dan membahasnya dengan orang lain. Bukan Cuma itu, siswa perlu "mengerjakannya", yakni menggambarkan sesuatu dengan cara mereka sendiri, menunjukkan contohnya, mencoba mempraktekkan keterampilan dan mengerjakan tugas yang menuntut pengetahuan yang telah mereka dapatkan.

Penelitian ini menggunakan penelitian tindakan (action research) sebanyak tiga putaran. Setian putaran terdiri dari empat tahap yaitu: rancangan, kegiatan dan pengamatan, refleksi, dan refisi. Sasaran penelitian ini adalh siswa Kelas II Sd Negeri 200403 Padangsidimpuan Tahun Pelajaran 2015/2016. Data yang diperoleh berupa hasil tes formatif, lembar observasi kegiatan belajar mengajar.

Dari hasil analis didapatkan bahwa prestasi belajar siswa mengalami peningkatan dari siklus I sampai siklus III yaitu, siklus I (64,00\%), siklus II (76,00\%), siklus III $(88,00 \%)$.

Simpulan dari penelitian ini adalah pembelajaran kontekstual berbasis masalah dapat berpengaruh positif terhadap motivasi belajar Siswa Kelas II Sd Negeri 200403 Padangsidimpuan Tahun Pelajaran 2015/2016, serta model pembelajaran ini dapat digunakan sebagai salah satu alternative pembelajaran IPA.

\section{PENDAHULUAN}

Pembangunan Nasional di bidang pengembangan sumberdaya manusia Indonesia yang berkualitas melalui pendidikan merupakan upaya yang sungguh-sungguh dan terus-menerus dilakukan untuk mewujudkan manusia Indonesia seutuhnya. Sumberdaya yang berkualitas akan menentukan mutu kehidupan pribadi, masyarakat, dan bangsa dalam rangka mengantisipasi, mengatasi persoalan-persoalan, dan tantangan-tantangan yang terjadi dalam masyarakat pada kini dan masa depan.

Salah satu permasalahan yang dihadapi oleh bangsa Indonesia adalah rendahnya mutu pendidikan, khususnya pendidikan dasar dan menengah. Berbagai usaha telah dilakukan untuk menigkatkan mutu pendidikan nasional, antara lain melalui berbagai pelatihan dan peningkatan kualitas guru, penyempurnaan kurikulum,

pengadaan buku dan alat pelajaran, perbaikan sarana dan prasarana pendidikan lain, dan peningkatan mutu manajemen sekolah, namun demikian, berbagai indikator mutu pendidikan belum menunjukkan peningkatan yang memadai.

Upaya peningkatan kualitas pendidikan di Indonesia tidak pernah berhenti. Berbagai terobosan baru terus dilakukan oleh pemerintah melalui Depdiknas. Upaya itu antara lain dalam pengelolaan sekolah, peningkatan sumber daya tenaga pendidikan, pengembangan/penulisan materi ajar, serta pengembangan paradigma baru dengan metodologi pengajaran.

Mengajar bukan semata persoalan menceritakan. Belajar bukanlah konsekuensi otomatis dari perenungan informasi ke dalam benak siswa. Belajar memerlukan keterlibatan 
mental dan kerja siswa sendiri. Penjelasan dan pembelajaran diterapkan dan bagaimana hasil pemeragaan semata tidak akan membuahkan yang diinginkan dapat dicapai.

hasil belajar yang langgeng. Yang bisa membuahkan hasil belajar yang langgeng hanyalah kegiatan belajar aktif.

Apa yang menjadikan belajar aktif? Agar belajar menjadi aktif siswa harus mengerjakan banyak sekali tugas. Mereka harus menggunakan otak, mengkaji gagasan, memecahkan masalah, dan menerapkan apa yang mereka pelajari. Belajar akif harus gesit, menyenangkan, bersemangat dan penuh gairah. Siswa bahkan sering meninggalkan tempat duduk mereka, bergerak leluasa dan berfikir keras (moving about dan thinking aloud)

Untuk bisa mempelajari sesuatu dengan baik, kita perlu mendengar, melihat, mengajukan pertanyaan tentangnya, dan membahasnya dengan orang lain. Bukan Cuma itu, siswa perlu "mengerjakannya", yakni menggambarkan sesuatu dengan cara mereka sendiri, menunjukkan contohnya, mencoba mempraktekkan keterampilan, dan mengerjakan tugas yang menuntut pengetahuan yang telah atau harus mereka dapatkan.

Dengan menyadari gejala-gejala atau kenyataan tersebut diatas, maka dalam penelitian ini penulis penulis mengambil judul

$\begin{array}{lrr}\text { "EFEKTIVITAS } & \text { PEMBELAJARAN } \\ \text { KONTEKSTUAL MODEL PENGAJARAN } \\ \text { BERBASIS MASALAH } & \text { DALAM } \\ \text { MENINGKATKAN } & \text { PRESTASI } & \text { DAN } \\ \text { PENGUASAAN MATERI PELAJARAN IPA } \\ \text { SISWA KELAS II SD NEGERI } & \text { 200403 } \\ \text { PADANGSIDIMPUAN } & \text { TAHUN } \\ \text { PELAJARAN 2015/2016." } & \end{array}$

\section{METODE PENELITTIAN}

Penelitian ini merupakan penelitian tindakan (action research), karena penelitian dilakukan untuk memecahkan masalah pembelajaran di kelas. Penelitian ini juga termasuk penelitian deskriptif, sebab menggambarkan bagaimana suatu teknik
Menurut Sukidin dkk. (2002:54) ada 4 macam bentuk penelitian tindakan, yaitu:(1) penelitian tindakan guru sebagai peneliti, (2) penelitian tindakan kolaboratif, (3) penelitian tindakan simultan terintegratif, dan (4) penelitian tindakan sosial eksperimental.

Keempat bentuk penelitian tindakan di atas, ada persamaan dan perbedaannya. Menurut Oja dan Smulyan sebagaimana dikutip oleh Kasbolah, (dalam Sukidin, dkk. 2002:55), ciriciri dari setiap penelitian tergantung pada:(1) tujuan utamanya atau pada tekanannya, (2) tingkat kolaborasi antara pelaku peneliti dan peneliti dari luar, (3) proses yang digunakan dalam melakukan penelitian, dan (4) hubungan antara proyek dengan sekolah.

Dalam penelitian ini menggunakan bentuk guru sebagai peneliti, dimana guru sangat berperan sekali dalam proses penelitian tindakan kelas. Dalam bentuk ini, tujuan utama penelitian tindakan Kelas IValah untuk meningkatkan praktik-praktik pembelajaran di kelas. Dalam kegiatan ini, guru terlibat langsung secara penuh dalam proses perencanaan, tindakan, observasi, dan refleksi. Kehadiran pihak lain dalam penelitian ini peranannya tidak dominan dan sangat kecil.

Penelitian ini mengacu pada perbaikan pembelajaran yang berkesinambungan. Kemmis dan Taggart (1988:14) menyatakan bahwa model penelitian tindakan adalah berbentuk spiral. Tahapan penelitian tindakan pada suatu siklus meliputi perencanaan atau pelaksanaan observasi dan refleksi. Siklus ini berlanjut dan akan dihentikan jika sesuai dengan kebutuhan dan dirasa sudah cukup. 


\section{HASIL PENELITIAN DAN PEMBAHASAN}

Data lembar observasi diambil dari dua pengamatan yaitu data pengamatan pengelolaan metode pembelajaran kontekstual model pengajaran berbasis masalah yang digunakan untuk mengetahui pengaruh penerapan metode pembelajaran kontekstual model pengajaran berbasis masalah dalam meningkatkan prestasi belajar siswa dan data pengamatan aktivitas siswa dan guru.

Data tes formatif untuk mengetahui peningkatan prestasi belajar siswa setelah diterapkan metode pembelajaran kontekstual model pengajaran berbasis masalah.

\section{A. Analisis Data Penelitian Persiklus}

1. Siklus I

a. Tahap Perencanaan

Pada tahap ini peneliti mempersiapkan perangkat pembelajaran yang terdiri dari rencana pelajaran 1 , soal tes formatif 1 dan alat-alat pengajaran yang mendukung.

b. Tahap Kegiatan dan Pelaksanaan

Pelaksanaan kegiatan belajar mengajar untuk siklus I dilaksanakan pada tanggal 4 Oktober 2016 di Kelas II dengan jumlah siswa 21 siswa. Dalam hal ini peneliti bertindak sebagai guru. Adapun proses belajar mengajar mengacu pada rencana pelajaran yang telah dipersiapkan. Pengamatan (observasi) dilaksanakan bersamaan dengan pelaksaaan belajar mengajar.
Tabel 4.2. Rekapitulasi Hasil Tes Formatif Siswa pada Siklus I

\begin{tabular}{|c|l|c|}
\hline No & \multicolumn{1}{|c|}{ Uraian } & $\begin{array}{c}\text { Hasil } \\
\text { Siklus I }\end{array}$ \\
\hline 1 & $\begin{array}{l}\text { Nilai rata-rata tes } \\
\text { formatif } \\
2\end{array}$ & $\begin{array}{l}\text { Jumlah siswa yang } \\
\text { tuntas belajar } \\
\text { Persentase } \\
\text { ketuntasan belajar }\end{array}$ \\
\hline
\end{tabular}

$\begin{array}{r}\text { Dari tabel di atas dapat } \\ \text { dijelaskan bahwa } \\ \text { menerapkan }\end{array}$
kontekstual model pengajaran
berbasis masalah diperoleh nilai
rata-rata prestasi belajar siswa
adalah 66,40 dan ketuntasan belajar
mencapai $64,00 \%$ atau ada 13 siswa
dari 25 siswa sudah tuntas belajar.
Hasil tersebut menunjukkan bahwa
pada siklus pertama secara klasikal
siswa belum tuntas belajar, karena
siswa yang memperoleh nilai $\geq 65$
hanya sebesar $64,00 \%$ lebih kecil
dari persentase ketuntasan yang
dikehendaki yaitu sebesar $85 \%$. Hal
ini disebabkan karena siswa masih
asing dengan diterapkannya
pembelajaran kontekstual model
pengajaran berbasis masalah.

2. Siklus II

a. Tahap perencanaan

Pada tahap ini peneliti mempersiapkan perangkat pembelajaran yang terdiri dari rencana pelajaran 2 , soal tes formatif II dan alat-alat pengajaran yang mendukung. 
b. Tahap kegiatan dan pelaksanaan

Pelaksanaan kegiatan belajar mengajar untuk siklus II dilaksanakan pada tanggal 11 Oktober 2016 di Kelas II dengan jumlah siswa 21 siswa. Dalam hal ini peneliti bertindak sebagai guru. Adapun proses belajar mengajar mengacu pada rencana pelajaran dengan memperhatikan revisi pada siklus I, sehingga kesalah atau kekurangan pada siklus I tidak terulanga lagi pada siklus II. Pengamatan (observasi) dilaksanakan bersamaan dengan pelaksanaan belajar mengajar.

Tabel 4.4. Hasil Tes Formatif Siswa pada Siklus II

\begin{tabular}{|c|l|c|}
\hline No & \multicolumn{1}{|c|}{ Uraian } & $\begin{array}{c}\text { Hasil } \\
\text { Siklus II }\end{array}$ \\
\hline 1 & $\begin{array}{l}\text { Nilai rata-rata tes } \\
\text { formatif }\end{array}$ & 71,20 \\
3 & $\begin{array}{l}\text { Jumlah siswa yang } \\
\text { tuntas belajar } \\
\text { Persentase } \\
\text { ketuntasan belajar }\end{array}$ & 76,00 \\
\hline
\end{tabular}

Dari tabel di atas diperoleh nilai rata-rata prestasi belajar siswa adalah 71,20 dan ketuntasan belajar mencapai $76,00 \%$ atau ada 16 siswa dari 21 siswa sudah tuntas belajar. Hasil ini menunjukkan bahwa pada siklus II ini ketuntasan belajar secara klasikal telah mengalami peningkatan sedikit lebih baik dari siklus I. Adanya peningkatan hasil belajar siswa ini karena siswa sudah mulai akrab dan menemuan keasyikan dengan metode pembelajaran kontekstual model pengajaran berbasis masalah. Disamping itu kemampuan guru dalam mengelola proses belajar mengajar dalam metode ini juga semakin meningkat sehingga proses belalar-mengajar semakin efektif.

\section{Siklus III}

a. Tahap Perencanaan

Pada tahap ini peneliti mempersiapkan perangkat pembelajaran yang terdiri dari rencana pelajaran 3 , soal tes formatif 3 dan alat-alat pengajaran yang mendukung.

b. Tahap kegiatan dan pengamatan

Pelaksanaan kegiatan belajar mengajar untuk siklus III dilaksanakan pada tanggal 18 Oktober 2016 di Kelas II dengan jumlah siswa 21 siswa. Dalam hal ini peneliti bertindak sebagai guru. Adapun proses belajar mengajar mengacu pada rencana pelajaran dengan memperhatikan revisi pada siklus II, sehingga kesalahan atau kekurangan pada siklus II tidak terulang lagi pada siklus III. Pengamatan (observasi) dilaksanakan bersamaan dengan pelaksanaan belajar mengajar.

Tabel 4.6. Hasil Tes Formatif Siswa pada Siklus III

\begin{tabular}{|c|l|c|}
\hline No & \multicolumn{1}{|c|}{ Uraian } & $\begin{array}{c}\text { Hasil Siklus } \\
\text { III }\end{array}$ \\
\hline 1 & $\begin{array}{l}\text { Nilai rata-rata tes } \\
\text { formatif }\end{array}$ & 77,20 \\
3 & $\begin{array}{l}\text { Jumlah siswa yang } \\
\text { tuntas belajar } \\
\text { Persentase } \\
\text { ketuntasan belajar }\end{array}$ & 88,00 \\
\hline
\end{tabular}


Berdasarkan tabel diatas diperoleh nilai rata-rata tes formatif sebesar 77,20 dan dari 21 siswa yang telah tuntas sebanyak 19 siswa dan 2 siswa belum mencapai ketuntasan belajar. Maka secara klasikal ketuntasan belajar yang telah tercapai sebesar $88,00 \%$ (termasuk kategori tuntas). Hasil pada siklus III ini mengalami peningkatan lebih baik dari siklus II. Adanya peningkatan hasil belajar pada siklus III ini dipengaruhi oleh adanya peningkatan kemampuan siswa mempelajari materi pelajaran yang telah diterapkan selama ini. Disamping itu dengan adanya metode pembelajaran ini siswa dapat bertanya dengan sesama temanya, dan ternyata dari proses bertanya antar siswa ini, siswa lebih mudah menerima penjelasan dari temannya yang lebih paham tengtang materi pelejaran tersebut. Juga dari hasil pembelajaran kontekstual model pengajaran berbasis masalah ini murid jadi lebih mudah untuk bekerja sama dengan sesama temanya.

c. Refleksi

Pada tahap ini akah dikaji apa yang telah terlaksana dengan baik maupun yang masih kurang baik dalam proses belajar mengajar dengan penerapan metode pembelajaran kontekstual model pengajaran berbasis masalah. Dari data-data yang telah diperoleh dapat duraikan sebagai berikut:

1. Selama proses belajar mengajar guru telah melaksanakan semua pembelajaran dengan baik. Meskipun ada beberapa aspek yang belum sempurna, tetapi persentase pelaksanaannya untuk masing-masing aspek cukup besar.

2. Berdasarkan data hasil pengamatan diketahui bahwa siswa aktif selama proses belajar berlangsung.

3. Kekurangan pada siklus-siklus sebelumnya sudah mengalami perbaikan dan peningkatan sehingga menjadi lebih baik.

4. Hasil belajar siswsa pada siklus III mencapai ketuntasan.

d. Revisi Pelaksanaan

Pada siklus III guru telah menerapkan metode pembelajaran kontekstual model pengajaran berbasis masalah dengan baik dan dilihat dari aktivitas siswa serta hasil belajar siswa pelaksanaan proses belajar mengajar sudah berjalan dengan baik. Maka tidak diperlukan revisi terlalu banyak, tetapi yang perlu diperhatikan untuk tindakah selanjutnya adalah memaksimalkan dan mempertahankan apa yang telah ada dengan tujuan agar pada pelaksanaan proses belajar mengajar selanjutnya penerapan metode pembelajaran kontekstual model pengajaran berbasis masalah dapat meningkatkan proses belajar mengajar sehingga tujuan pembelajaran dapat tercapai.

\section{B. Pembahasan}

1. Ketuntasan Hasil belajar Siswa

Melalui hasil peneilitian ini menunjukkan bahwa pembelajaran kontekstual model pengajaran berbasis masalah memiliki dampak positif dalam meningkatkan daya ingat siswa. Hal ini dapat dilihat dari semakin mantapnya pemahaman dan penguasaan siswa terhadap materi yang telah disampaikan guru selama ini (ketuntasan belajar meningkat dari sklus I, II, dan III) yaitu masing-masing $64,00 \%, 76,00 \%$, dan 
88,00\%. Pada siklus III ketuntasan KESIMPULAN

belajar siswa secara klasikal telah tercapai.

2. Kemampuan Guru dalam Mengelola Pembelajaran

Berdasarkan analisis data, diperoleh aktivitas siswa dalam proses pembelajaran kontekstual model pengajaran berbasis masalah dalam setiap siklus mengalami peningkatan. Hal ini berdampak positif terhadap proses mengingat kembali materi pelajaran yang telah diterima selama ini, yaitu dapat ditunjukkan dengan meningkatnya nilai rata-rata siswa pada setiap siklus yang terus mengalami peningkatan.

3. Aktivitas Guru dan Siswa Dalam Pembelajaran

Berdasarkan analisis data, diperoleh aktivitas siswa dalam proses pembelajaran IPA dengan pembelajaran kontekstual model pengajaran berbasis masalah yang paling dominan adalah bekerja dengan menggunakan alat/media, mendengarkan/memperhatikan

penjelasan guru, dan diskusi antar siswa/antara siswa dengan guru. Jadi dapat dikatakan bahwa aktivitas isiwa dapat dikategorikan aktif.

Sedangkan untuk aktivitas guru selama pembelajaran telah melaksanakan langkah-langkah metode pembelajaran kontekstual model pengajaran berbasis masalahdengan baik. Hal ini terlihat dari aktivitas guru yang muncul di antaranya aktivitas membimbing dan mengamati siswa dalam mengerjakan kegiatan, menjelaskan/melatih menggunakan alat, memberi umpan balik/evaluasi/tanya jawab dimana prosentase untuk aktivitas di atas cukup besar.

Dari hasil kegiatan pembelajaran yang telah dilakukan selama tiga siklus, dan berdasarkan seluruh pembahasan serta analisis yang telah dilakukan dapat disimpulkan sebagai berikut:

1. Pembelajaran dengan pembelajaran kontekstual model pengajaran berbasis masalah memiliki dampak positif dalam meningkatkan prestasi belajar siswa yang ditandai dengan peningkatan ketuntasan belajar siswa dalam setiap siklus, yaitu siklus I $(64,00 \%)$, siklus II $(76,00 \%)$, siklus III $(88,00 \%)$.

1. Penerapan pembelajaran kontekstual model pengajaran berbasis masalah mempunyai pengaruh positif, yaitu dapat meningkatkan motivasi belajar siswa untuk mempelajari materi pelajaran yang diterima selama ini, dimana hal tersebut ditunjukan dengan rata-rata sikap siswa yang menyatakan bahwa siswa tertarik dan berminat dengan pembelajaran kontekstual model pengajaran berbasis masalah sehingga mereka menjadi termotivasi untuk belajar.

2. Pembelajaran kontekstual model pengajaran berbasis masalah memiliki dampak positif terhadap pemahaman materi pelajaran yang diajaran, dimana dengan metode ini siswa dipaksa untuk memecahkan masalah yang beruhubungan dengan materi palajaran yang diajarkan.

\section{DAFTAR PUSTAKA}

Arikunto, Suharsimi. ..... Prosedur Penelitian Suatu Pendekatan Praktek. Jakarta: Rineksa Cipta

Ali, Muhammad. 1996. Guru Dalam Proses Belajar Mengajar. Bandung: Sinar Baru Algesindon.

Daroeso, Bambang. 1989. Dasar dan Konsep Pendidikan Moral Pancasila. Semarang: Aneka Ilmu.

Dayan, Anto. 1972. Pengantar Metode Statistik Deskriptif, tt. Lembaga Penelitian 
Volume 3 Nomor 1, Halaman 1-81, Januari--Juni 2018

RISTEKDIK | Jurnal Bimbingan dan Konseling

P-ISSN: 2527-4244, E-ISSN : 2541-206X

Pendidian dan Penerangan

Ekonomi.

Hadi, Sutrisno. 198. Metodologi Research, Jilid

1. Yogyakarta: YP. Fak. Psikologi UGM.

Melvin, L. Siberman. 2004. Aktif Learning, 101

Cara Belajar Siswa Aktif.

Bandung: Nusamedia dan Nuansa.

Ngalim, Purwanto M. 1990. Psikologi

Pendidikan. Bandung: PT. Remaja

Rosdakarya.

Riduwan. 2000. Belajar Mudah Penelitian untuk

Guru-Karyawan dan Peneliti

Pemula. Bandung: Alfabeta.

Sukmadinata, Nana Syaodih. 2000. Metode

Penelitian Pendidikan. Bandung:

PT. Remaja Rosdakarya.

Surakhmad, Winarno. 1990. Metode

Pengajaran Nasional. Bandung: Jemmars. 